\title{
Captain, My Captain: A Look at Autonomous Ships AND HOW THEY SHOULD OPERATE UNDER ADMIRALTY LAW
}

\author{
SAMANTHA JORDAN ${ }^{*}$
}

\section{INTRODUCTION}

It's a moonless night on the open seas, where a massive container ship is steaming full speed ahead to her destination when she receives the latest weather report. There's a nor'easter brewing on the horizon. The ship plots the best route of avoidance and alters her course and speed to skirt the worst of it and ensure an on-time arrival at its destination. The ship's owners and the harbormaster at her next port of call are advised of the revised route and reason for deviation. As the vessel nears port she utilizes the channel ranges and aids to navigation to safety moor alongside the dock.

At first glance this appears to be just another routine transit for a cargo ship engaged in transcontinental shipping. The truth is, it is not, this ship has no berthing quarters, navigational bridge or galley because this ship has no one aboard, she is a ghost ship. Commanded from an operating center on the other side of the world, where shore-based operators are monitoring and controlling this vessel and a fleet of others just like her through satellite data links - that is, when the ship isn't just controlling herself. "Although robotic ships of this sort are some ways off in the future, it's not a question of if they will happen but when."

Industrial leaders such as Rolls-Royce, Kongsburg, Yara, Imarsat and Wilhelmsen have been developing technology to make autonomous ships a reality. ${ }^{2}$ In fact, Rolls-Royce expects that the company will begin making short voyages by 2020, and Ocean-going voyages by 2025 with their autonomous ships. ${ }^{3}$ As Jon Walker explains "Yara provides a perfect example of how we will see the technology used in the very near future. Yara and Kongsberg have already

* J.D., 2020 (expected), Indiana University Robert H. McKinney School of Law; B.S., 2017, University of Houston. The author wishes to thank Gerard Magliocca and Aila Hoss, who provided invaluable feedback and guidance, as well as the members of the Indiana International \& Comparative Law Review.

1. Oskar Levander, Forget Autonomous Cars-Autonomous Ships Are Almost Here, IEEE SPECTRUM (Jan. 28, 2017, 17:00 GMT), https://spectrum.ieee.org/transportation/marine/forgetautonomous-cars-autonomous-ships-are-almost-here [https://perma.cc/3KWS-LL7X].

2. Inmarsat Partners with Rolls Royce on Autonomous Ship Project, InMARSAT (Sept. 8, 2015). https:/www.inmarsat.com/press-release/inmarsat-partners-with-rolls-royce-on-autonomousship-project/ [https://perma.cc/8SMM-4L8A]; see also Wilhelmsen and Kongsberg Establish World's First Autonomous Shipping Company, Kongsberg (Mar. 8, 2018), https://www. kongsberg.com/en/kog/news/2018/april/wilhelmsen\%20and\%20kongsberg\%20establish\%20wo rlds\%20first\%20autonomous\%20shipping\%20company/ [https://perma.cc/8LCZ-NTVA].

3. Jon Walker, Autonomous Ships Timeline-Comparing Rolls-Royce, Kongsberg, Yara and More, EMERJ, https://www.techemergence.com/autonomous-ships-timeline/ (last updated May 9, 2019) [https://perma.cc/27HL-DTDY]. 
launched the first autonomous and fully electric cargo ship. ${ }^{4}$ The vessel christened YARA Birkeland - started as a manned ship in 2018. ${ }^{5}$ The plan is to test the new vessel and slowly transfer more responsibility to the Artificial Intelligence system. Their goal is to have remote operations in late 2019 and fully autonomous operations by $2020 .{ }^{\prime \prime}$

Many industry experts believe that autonomous transits will start in the next few years, with remote and autonomous ships on short and routine trips with defined routes by the end of the decade. ${ }^{7}$ These experts anticipate artificial shipboard intelligence to gradually improve to the point where cargo ships are sailing transcontinental voyages without crews (possibly between 2020 and 2025, based on projections). ${ }^{8}$ As these companies implement the new technology to allow ships to be remotely controlled or operate autonomously, it is forecasted that the shipping industry will adopt the technology quickly due to the cost savings. ${ }^{9}$

More challenging to the future of autonomous ships are the regulatory changes required to allow such ships to operate. ${ }^{10}$ Currently, global shipping regulations are unclear about whether these ships would be allowed to operate nationally as well as internationally, how they could be insured, and who would be legally liable for damages and pollution in the event of an accident. ${ }^{11}$

This Note seeks to identify the legal hurdles facing the implementation of autonomous ships and suggests areas of future considerations that policymakers should keep in mind. The first section will discuss the benefits of autonomous vessels. The second section will identify the various types of autonomous vessels. The third section of this Note will identify and discuss international laws that would be applied to autonomous vessels, and how those laws would impact the use of autonomous vessels. The fourth section of this Note will provide recommendations on how current international laws should be interpreted or amended to allow for autonomous vessels.

\section{BENEFITS OF AUTONOMOUS SHIPS}

\section{A. Globalization and International Commerce}

Globalization and international commerce was, and continues to be built on

\footnotetext{
4. $I d$.

5. $I d$.

6. Id.

7. Id.

8. Id.

9. Walker, supra note 3.

10. Jouni Saarni, Sini Nordberg-Davis \& Hannu Makkonen, From Innovation to MarketsRedefining Shipping, in Remote and Autonomous Ships-The Next Steps, 74-85, 82 (RollsRoyce PLC. 2016), https://www.rolls-royce.com/ /media/Files/R/Rolls-Royce/documents/ customers/marine/ship-intel/aawa-whitepaper-210616.pdf [https://perma.cc/2UP4-XXSK].

11. Id. at 81 .
} 
seaborne trade because it is often the most cost effective way to move large volumes of goods from one country to another. " "The United Nations Conference on Trade and Development estimated that in 2015, total seaborne trade volume surpassed 10 billion tons for the first time - roughly a four-fold increase since 1970." 13 The international maritime shipping industry is responsible for the carriage of almost $90 \%$ of world trade, "shipping is the life blood of the global economy" and thus the future of shipping is of paramount importance to the world economy. ${ }^{14}$ Utilizing cargo ships is generally a much slower option than planes, trucks, or rail, so their appeal is due to being a much lower cost option. ${ }^{15}$ The need to keep costs low have sparked increased innovation in the shipping industry to keep themselves a viable option for the transportation of goods. ${ }^{16}$ The maritime shipping industry has brought down the cost of transportation by use of containerization, enabling more goods to be carried per transit, and reducing crew costs, making shipping products that previously had too low of a profit margin across the world economically viable, this has opened new global market opportunities. ${ }^{17}$

Once the autonomous technology reaches maturity and proves to be safe and reliable, some companies and investors believe the cost savings of autonomous vessels will result in rapid adoption in the industry. ${ }^{18}$ The development of autonomous shipping technology is not just to reduce overhead costs and human error, but to allow a real transformation within the shipping and ship building industries. ${ }^{19}$ Without requiring a crew to be onboard, ships can be designed with efficiency in mind, creating vessels without decks, bathrooms, kitchens, and sleeping quarters required on today's vessels. ${ }^{20}$ The effects of these newly designed ships will be felt in multiple industries. The ability to cut cost through the use of autonomous ships would provide cost savings for those shipping goods along with fostering new market possibilities. ${ }^{21}$ For example, items that were

12. Shipping and World Trade, International Chamber of Shipping, http://www.icsshipping.org/shipping-facts/shipping-and-world-trade (last visited Jan. 10, 2019) [https://perma.cc/ JG8M-TP7P].

13. Walker, supra note 3.

14. Saarni, Nordberg-Davis \& Makkonen supra note 10.

15. Id.

16. Stefan Seltz-Axmacher, How One Change to Shipping Goods Could Change the Way We Live, WORLD ECON. ForUM, (Sept. 2019), https://www.weforum.org/agenda/2019/09/from-sail-toself-driving-what-the-history-of-shipping-tells-us-about-the-future-of-autonomous-electric-freight/ [https://perma.cc/XLP3-ZDF5].

17. Id.

18. Saarni, Nordberg-Davis \& Makkonen, supra note 10.

19. Id.

20. Luci Carey, All Hands off Deck? The Legal Barriers to Autonomous Ships 1-32, 3 NAT'L UnIV. Sing. CTR. MAR. L., Working Paper 17/06, 2017, https://law.nus.edu.sg/cml/pdfs/wps/CMLWPS-1706.pdf [https://perma.cc/ZU4H-HEW8].

21. Walker, supra note 3. 
previously impractical to ship could now produce a profit. ${ }^{22}$ We have seen this before through the use of containerization, which made shipping products globally more cost effective. ${ }^{23}$ Products with relatively low profit margins will enter previously unavailable markets, which fosters heightened competition in sectors where none had previously existed. ${ }^{24}$

\section{B. Unavailability of Qualified Seafarers}

The use of autonomous vessels would not only increase globalization and open the international market, it would also eliminate the issue of finding qualified seafarers to man vessels. ${ }^{25}$ Although international trade has grown significantly over the last two decades, becoming the leading form of transportation for goods, the maritime industry has been unable to recruit, train, and retain the amount of merchant marines needed to man vessels. ${ }^{26}$ Long voyages away from family, along with the inherently unique risk of the profession, such as injury, illness, and piracy provide deterrents to seeking a career on shipping vessels. Making the effort to find qualified seafarers harder is the $\$ 25,000$ a year starting salary. ${ }^{27}$ With large cargo vessels employing a crew upwards of twenty-five skilled mariners, costs the shipping company an average of $\$ 4,000$ a day, which represents the second largest operating expense for shipowners. ${ }^{28}$

\section{Safety and Security}

Another benefit of autonomous ships is that once full integrated they are expected to be safer than ships currently manned and piloted by humans. ${ }^{29}$ According to a report published by the Munich-based insurance company Allianz

22. Id.

23. Id.

24. Id.

25. Raunek, Can Futuristic Unmanned Cargo Ships Sail Without Seafarers, MARINE INSIGHT, (Dec. 2019)

https://www.marineinsight.com/future-shipping/rolls-royces-futuristic-unmanned-ships-will-sailwithout-seafarers/ [https://perma.cc/SV6W-4RP3].

26. Michal Chwedczuk, Analysis of the Legal Status of Unmanned Commercial Vessels in U.S. Admiralty and Maritime Law, 47 J. MAR. L \& CoM. 123, 1284 (2016).

27. Average Seafarers Internal Union Salary, PayScale (Nov. 18, 2018), https://www. payscale.com/research/US/Employer=Seafarers_International_Union/Salary [https://perma.cc/4TE2-PHGQ].

28. Evan Ackerman, Unmanned Cargo Ships Face Industry Resistance, Are a Good Idea Anyway, IEEE SPECTRUM (Feb. 27, 2014), http://spectrum.iee.org/automaton/robotics/ industrial-robots/unmanned-cargo-ships-face-industry-resistance-are-a-good-idea-anyway [https://perma.cc/447C-QFZM].

29. Amar Toor, Could Autonomous Ships Make the Open Seas Safer?, The Verge (Oct. 12, 2015, 10:25 AM), https:/www.theverge.com/2015/10/12/9504761/rolls-royce-autonomousunmanned-shipping-illegal [https://perma.cc/MK2H-VXUM]. 
in 2012, between 75 and 96 percent of marine accidents are a result of human error, often the result of fatigue. ${ }^{30}$ Remotely controlled and autonomous ships would eliminate shipboard human error and injury to crew, and dangers to the ship itself. ${ }^{31}$

Without a crew, the threats of piracy would also be mitigated. ${ }^{32}$ Holding crew members for hostage in exchange for ransom is a leading force behind modern piracy.$^{33}$ According to the State of Maritime Piracy report, last year there were 18 incidents of kidnapping for ransom off the coast of West Africa. ${ }^{34}$

The economic cost of just Somali piracy was estimated at $\$ 1.7$ billion in 2016 and $\$ 7$ billion in 2010. ${ }^{35}$ Pirate attacks in Sulu and Celebes Seas results in some merchants choosing to change their routes which can mean longer delivery times and an increase in fuel costs, limiting the economic benefit of the maritime shipping industry. ${ }^{36}$

\section{WHAT IS AN AUTONOMOUS SHIP?}

\section{A. Terminology}

There is no globally or even regionally accepted definition for what an "autonomous vessels" and "unmanned vessels" is. For the purposes of this Note, "autonomous ships" are considered to be ships capable of being controlled remotely or use onboard algorithms to make or supply navigational decisions or having the ability to autonomously control and manage the ship. ${ }^{37}$

\section{B. Levels of Autonomy}

This Note will adopt Lloyd's Register's description of ship autonomy levels which is determined by the level of autonomy that the ship is utilizing and the supervision required by the shore-based operator.

30. Sven Gerhard, Safety and Shipping 1912-2012 From the Titanic to Costa Concordia: An Insurrer's Perspective from Allianz Global Corporate \& Specialty 6 (Carley Fields ed. 2012).

31. Id.

32. Harry Wise, Autonomous Shipping: The Future of Seafaring, in THE MANUFACTURER (Dec. 12, 2018).

33. Id.

34. The State of Maritime Piracy 2017, Assessing the Economic and Human Cost, OcEANS BEYOND PIRACY (May 23, 2018), http://oceansbeyondpiracy.org/reports/sop [https://perma.cc/ 2VRL-ZRZ8].

35. Luke Graham, Somali Piracy Is Back With A \$1.7 Billion Problem After Shipping Firms Lower Vigilance, CNBC, (May 2017), https:/www.cnbc.com/2017/05/03/somali-piracy-is-back17-billion-dollar-problem-shipping-firms-lower-vigilance.html [https://perma.cc/6P4L-ZJKS].

36. The State of Maritime Piracy 2017, supra note 34.

37. Danish Maritime Authority, Analysis of Regulatory Barriers to the use of Autonomous Ships 3-4 (Dec. 2017). 
Table 2: Autonomy levels in a regulatory context ${ }^{38}$

\begin{tabular}{|l|l|}
\hline Autonomy level & Operator's role \\
\hline $\begin{array}{l}\text { M: Manual navigation with } \\
\text { automated processes and decision } \\
\text { support }\end{array}$ & $\begin{array}{l}\text { The operator (master) is on board } \\
\text { controlling the ship which is manned as } \\
\text { per current manning standards. Subject } \\
\text { to sufficient technical support options } \\
\text { and warning systems, the bridge may at } \\
\text { times be unmanned with an officer on } \\
\text { standby ready to take control and } \\
\text { assume the navigational watch. }\end{array}$ \\
\hline $\begin{array}{l}\text { R: Remote-controlled vessel with } \\
\text { crew on board }\end{array}$ & $\begin{array}{l}\text { The vessel is controlled and operated } \\
\text { from shore or from another vessel, but } \\
\text { a person trained for navigational watch } \\
\text { and maneuvering of the ship will be on } \\
\text { board on standby ready to receive } \\
\text { control and assume the navigational } \\
\text { watch, in which case the autonomy } \\
\text { level shifts to level M. }\end{array}$ \\
\hline $\begin{array}{l}\text { RU: Remote-controlled vessel } \\
\text { without crew on board }\end{array}$ & $\begin{array}{l}\text { The vessel is controlled from shore or } \\
\text { from another vessel and does not have } \\
\text { any crew on board. }\end{array}$ \\
\hline A: Autonomous vessel & $\begin{array}{l}\text { The operating system of the vessel } \\
\text { calculates consequences and risks. The } \\
\text { system is able to make decisions and } \\
\text { determine actions by itself. The } \\
\text { operator on shore is only involved in } \\
\text { decisions, if the system fails or prompts } \\
\text { for human intervention, in which case } \\
\text { the autonomy level will shift to level R } \\
\text { or RU, depending on whether there is } \\
\text { crew on board or not. }\end{array}$ \\
\hline
\end{tabular}

\section{Ship Operations}

In an effort to categorize autonomy levels, differing tables have been created by manufacturer and researchers. A common conclusion among companies pioneering autonomous ship development is these tables are of better use when evaluating subtasks rather than a holistic view of the entire autonomous

38. Id. at 6 . 
operation..$^{39}$

For autonomous ships, the link between the vessel's autonomy and requirement for human monitoring or control will be dependent on the subtask being executed. ${ }^{40}$ Depending on the decision-making tolerance, an autonomous ship can operate independent of human interaction in the adjusted or dynamic modes. ${ }^{41}$ The onboard intelligences system can accomplish simple tasking without operator intervention but when the tasks get more complex the level of interaction with the shore based operator is needed. ${ }^{42}$

While navigating on the open seas, the ship can be virtually fully autonomous, however in other parts of the voyage it will require exacting human supervision and decision making, or even full control over operations by the shore-based operator. ${ }^{43}$

To illustrate how an autonomous vessel would shift between levels of autonomy and control through various legs of a voyage, an example of a cargo ship is used below.

\section{Planning Stage}

Considerations made by the shore-based operator in the planning stage consist of determining the level of autonomy for each leg of the transit, the availability of reliable satellite communications, redundancy plans, and evaluating the sea readiness of the vessel. ${ }^{44}$

Autonomous vessels will use multiple combinations of satellite and landbased communication networks to relay information to the shore-based command center, owners, stakeholders and harbor masters. ${ }^{45}$ The majority of autonomous operations modes will require a reliable high bandwidth satellite communication system. ${ }^{46}$

However, adverse weather conditions pose a danger when the vessel is using the remote control or supervision modes due to the potential for latency or reduction in bandwidth speed. ${ }^{47}$ The operator must anticipate and monitor expected weather, satellite usage and locations to ensure continuous connectivity for the intended mission. ${ }^{48}$

In the voyage planning stage, the operator will have to plan the vessel's route, course and speed, then forecast the variables such as weather, connectivity, and

39. Esa Jokioinen, Introduction, in Remote And Autonomous ShIPS- The NeXt StePs, 313, 7 (Rolls-Royce plc. 2016).

40. Id.

41. Id.

42. Id.

43. Id.

44. Saarni, Nordberg, Davis \& Hakkonen, supra note 10.

45. Id at 8 .

46. Jokioinen, supra note 39.

47. Id.

48. Id. 
vessel traffic that would have an effect on the planned course. ${ }^{49}$ The operator, having gathered all of this information will then develop fallback strategies for each leg. ${ }^{50}$ If while on the voyage the ship loses connectivity with the command center, the vessel can automatically implement these fallback strategies. ${ }^{51}$

Within the range of fallback strategies would be for the ship to request that manual control be exerted, to change course and speed, to proceed to the next planned waypoint, or to stop the vessel and hold its position until given direction from the shore-based operator. ${ }^{52}$ These fallback strategies are contingent on the particular leg of the voyage. ${ }^{53}$ Depending on the conditions that the vessel is experiencing, these fallback strategies and autonomous thresholds can be modified through the continuous satellite link from the ship to the shore-based operator. $^{54}$

An onboard diagnostic system will be needed to run routine checks of the system to ensure proper operations and connections prior to the vessel departing port. ${ }^{55}$ While this diagnostic test can be run either on a regular interval by the vessel, or the shore-based operator, the use of stevedores will still be required to make sure that the vessel's cargo is secured. ${ }^{56}$

\section{a. Undocking Stage}

Once the ship is ready for departure from the dock, the use of a new mooring system adopted for autonomous vessels will have to be implemented. ${ }^{57}$ Depending on the port's structure and implementation of technology, mooring of the ship could be fully or semi-automatic. ${ }^{58}$ For tasking onboard the ship, when utilizing a full automatic mooring system, the subs tasking can be conducted by the shore based operator or by the autonomous vessel. ${ }^{59}$ Semi-automatic mooring means that the shore-based operator, through a connection to the ship would remotely operate the vessels winches. ${ }^{60}$ Economically speaking, both of these options require changes to the dockside infrastructure and duties of line handlers which means the use and development of these mooring system will require that the technology is capable of accommodating most autonomous ship. ${ }^{61}$ The

49. Id.

50. Id.

51. Id.

52. Id.

53. Id.

54. Id.

55. Id.

56. See generally Future Maritime Nautics, Autonomous Ships, 2016, https://www.sipotra.it/ old/wp-content/uploads/2017/05/Autonomous-Ships.pdf [https://perma.cc/6A5U-Y3U9].

57. Jokioinen, supra note 39.

58. $I d$.

59. Id at $8-9$.

60. Id. at 9 .

61. Id. 
maritime industry is currently exploring options already on the market for their capabilities of docking autonomous vessels. ${ }^{62}$ To ensure financial practicability this new system should be able to be utilized for both autonomous and crewed vessels. ${ }^{63}$ This would allow for the docking of all vessel at terminal docks, so that operations are not interrupted by only one type vessels being able to moor at specific docks. ${ }^{64}$

\section{b. Maneuvering within Port}

Once the autonomous ship has completed its diagnostic check and the cargo has been secure the shore-based operator will take direct control of the vessel to navigate her through the shipping channel ${ }^{65}$ Once the onboard avoidance system is tested and has performed repeated transits of the same port it would be possible for the vessel to navigate on its own from the dock through the shipping lanes and out to sea ${ }^{66}$ These operations must be conducted through high bandwidth and low latency communications networks between the vessel and the shoreside command center. ${ }^{67}$ This link can be provided by the use of satellites or even land-based networks while the ship is within range of the shore. ${ }^{68}$ Once the ship exceeds the range of shore-based communications the autonomous onboard system would seamlessly establish the link to the shore-based command center via satellite link. ${ }^{69}$

The technology is already in existences for shore-based operator to control the vessel in the form of direct joystick-type operation modes for dynamic positioning which locks speed, heading or relative position to an object. ${ }^{70}$ A more feasible solution rather than direct operation mode would be to send the vessel waypoints and permit the vessel to control the propulsion. ${ }^{71}$ In transit legs that provide little need for object avoidance the use of shore-based control and supervision would not be needed and the vessel would be able to proceed directly to autonomous mode. ${ }^{72}$

\section{c. Open Ocean Maneuvering}

The use of waypoints sent to the vessel would be the primary mode of

62. Id.

63. Jokioinen, supra note 39.

64. Id.

65. Krzystof Rrobel et al., Towards the Development of a System-Theoretic Model for Safety Assessment of Autonomous Merchant Vessels, 178 RELIABILITy ENGINEERING \& Sys. SAFETy 209, 210 (2017).

66. Jokioinen, supra note 39.

67. Id. at 7 .

68. Id.

69. Id.

70. $I d$.

71. Jokioinen, supra note 39.

72. Id. 
operations once the ship has successfully navigated through the shipping lanes and out to open waters. These waypoints are designated and assigned to the vessel in the planning phase. Once the vessel has reached its next waypoint it automictically continues to the next planned waypoint without the need for intervention from the shore-based operator. ${ }^{73}$ While in this autonomous mode the ship reports her location, heading, speed, and estimated time of arrival to the next waypoint back to the shore-based command center. ${ }^{74}$ Through the use of the ships radar, that is also displayed in the shore-based command center, the ship would provide her estimated distance to an area in which the vessel anticipates needing operator's supervision or control. ${ }^{75}$ While the vessel is in this mode autonomy is high and little operator control is needed as long as the voyage is proceeding as planned and no systems warrant attention. ${ }^{76}$

In the event that the ship's situational awareness system or autonomous navigation system's decision-making threshold is exceeded, the shore-based operator will be notified that intervention is required in order for the ship to safely navigate. ${ }^{77}$ If the vessel finds that a situation warrants the shore-based operators' intervention because there is a conflict with the voyage plan, then the system adjusts the autonomy level and advises the shore-based command center. ${ }^{78}$

Depending on the scenario the vessel will request differing levels of intervention from the operator. ${ }^{79}$ For example, a specific range deviation from the course between two waypoints can be set and if the vessel stays within those margins the autonomous navigation system notifies the operator about the deviation and gives the operator a limited time to override the course change. ${ }^{80}$ This deviation maybe require to take evasive action through making a slight adjustment to the vessel's course or speed to keep out of the way of vessel traffic. ${ }^{81}$ The shore-based operator would then communicate with the other vessel through the use VHF radio communication to alert other vessels or inform them of the passing or meeting arrangement. If the arrangement is unsafe for one or both vessels the operator could take full control and modify the course and speed to ensure the safety of the vessels. ${ }^{82}$

If a navigational challenge such as shoaling is presented, the shore-based operator will have to intervene and plan a new course or modify the waypoint because a slight course change would not be suitable to avoid the hazard to navigation. ${ }^{83}$ In this case the vessel will notify the shore-based operator and

73. Id.

74. Id.

75. Id.

76. Id.

77. Id.

78. Id.

79. $I d$.

80. Id. at 10 .

81. Id.

82. Id.

83. Id at $10-11$. 
supply alternative courses to the waypoint. ${ }^{84}$ The operator will then calculate the alternative courses that the onboard system supplied and confirm which course the vessel should proceed to follow to the next waypoint. ${ }^{85}$

When the autonomous navigation system encounters a scenario in which its navigation system planning protocol or algorithms cannot solve, shore-based operator intervention will be required. ${ }^{86}$ This situation would likely occur when a large number of crafts are operating in a confined waterway or other objects are detected and the path planning algorithms or radar systems are not capable of distinguishing the vessels or determining a safe course for avoidance. If the vessel encounters this situation the operational control system will immediately send a "pan-pan" message to the operator. ${ }^{87}$ This is the internationally recognized maritime message that alerts others of an urgent situation on the vessel, but that the situation does not pose an immediate danger to anyone's life or to the vessel. ${ }^{88}$ The vessel will then begin to execute the planned fallback strategies in a programed order until the shore-based operator intervenes. ${ }^{89}$

Autonomy levels will alter without shore-based intervention automatically within the preplanned perimeters depending on vessel traffic, position, weather conditions, and external forces..$^{90}$ As the ship encounters different scenarios, she learns from the decisions made by the shore-based operator and uses these situation and actions applying them to future scenarios. ${ }^{91}$ The need for the shorebased operators intervention will diminish in the future as more autonomous vessels enter the fleet and the onboard control systems share voyage plans and communicate with each other in real-time. ${ }^{92}$ While real-time interaction between autonomous vessels will make transits safer, manned vessels will always be sailing alongside the autonomous fleet, therefore the shore-based operators will be required until clear standards are established for communications between manned and unmanned vessels. ${ }^{93}$

\section{d. Maneuvering into Port}

Once the cargo ship is approaching her port of call the shore-based operator can again choose to take full control or increase the supervision level of the vessel. ${ }^{94}$ This might be necessary to comply with the traffic scheme of a Vessel

84. Id.

85. Id. at 11 .

86. Jokioinen, supra note 39.

87. Id. at 11 .

88. Id.

89. Id.

90. Autonomous and Remotely operated Ships, DNVGL, (Sept. 2018), at 67, http://rules. dnvgl.com/docs/pdf/dnvgl/cg/2018-09/dnvgl-cg-0264.pdf [https://perma.cc/69PU-GRK5].

91. Id.

92. Jokioinen, supra note 39.

93. Id. at 11 .

94. Id. at 12 . 
Traffic Service (VTS) or because piloting is required. ${ }^{95}$

Piloting requirement for compulsory pilot areas can be addressed in serval different ways. A possible solution that would allow autonomous vessels to moor or depart port would be to give the pilot the capability to take remote control over the autonomous vessel, or the shore-based vessel operator can hold a pilot license for the vessels ports of call that require pilotage. ${ }^{96}$ In areas that have a Vessel Traffic Service, policies regarding piloting procedures, practicalities, and reporting requirement can be adjusted on a case- by-case basis for the first vessels. ${ }^{97}$

Once the autonomous vessel is within range of the shore it is again possible for it to utilize land-based communications systems ${ }^{98}$. While transiting the harbor and port the vessel's navigation system can use geographical references such as ranges which show the vessels position within the channel to ensure the vessel is in the shipping lane..$^{99}$ Ports can also install cameras and radar systems that can aid in navigating the vessel safely alongside the dock. ${ }^{100}$

The above example gives an idea of how dynamic autonomy would work for autonomous ship operations. The type and level of autonomy will also be highly dependent on the ship type, size, operational area and conditions. The same principles would be followed by vessels of different sizes but the control and autonomy levels would be defined based on the vessels purpose. ${ }^{101}$

The greater variation and complexity the transit has, the more operator assistance and control the vessel will need until the algorithms evolve. ${ }^{102}$ In the case of a ferry making reciprocal crossings each day with limited variation in the transit, the autonomy level will be much higher. While the basic mission of the ferry generally does not vary, weather and traffic can change considerably. ${ }^{103}$ In this case it is likely that a crew will still be required to ensure the safety of the cargo and passengers while the ferry's transit is conducted autonomously. ${ }^{104}$

Ship-specific algorithms will be required even though the fundamentals of how they react autonomously to navigational conditions would follow the same principles. ${ }^{105}$ Due to reaction distance and time variations of vessels, different systems will also be required. ${ }^{106}$

\footnotetext{
95. Id.

96. Id.

97. Id.

98. Jokioinen, supra note 39.

99. Id. at 12 .

100. Id.

101. Id.

102. Id. at 19 .

103. Id. at 12 .

104. Id.

105. Id. at 20 .

106. Id. at 13 .
} 


\section{INTERNATIONAL ADMIRALTY LAWS}

Due to the inherent international nature of shipping and an international desire for homogeneous regulation of shipping after World War II, current shipping regulations are anchored in multilateral international conventions. ${ }^{107}$ These international conventions have been developed by the United Nations' specialized maritime agency, the International Maritime Organization (IMO).$^{108}$

The term maritime law is used to describing a wide range of laws, conventions, and other legal sources that regulate ships and their operations. ${ }^{109}$ Maritime law is comprised of a variety of legal systems, ranging from international law, regional, national and local rules. ${ }^{110}$ This framework regulates safety, security, and environmental protection as well as civil law matters, such as contracts of carriage, injuries to crew, liability and compensation for loss of cargo, salvage and marine risk and insurance. ${ }^{111}$

This Note will address three kinds of rules that would relate to the operation of autonomous ships. The first of which are jurisdictional rules, which provides for states' rights and obligations to regulate ships. These regulations are mainly found in the 1982 United Nations Convention on the Law of the Sea (UNCLOS). ${ }^{12}$ The second set of rules are those for safety, environmental concerns, along with training and watchkeeping standards. These rules are adopted through specialized United Nations agencies, such the International Maritime Organization (IMO). ${ }^{13}$ The third set of rules was adopted to address private law issues such as shipowners' civil liability for pollution, collisions or cargo-related losses and how such claims may be enforced. This set of rules is not as widely accepted as the public law conventions and may vary from nation to nation. ${ }^{14}$

\section{A. Law of the Sea (UNCLOS)}

The law of the sea deals with the rights and obligations of states over the seas. ${ }^{115}$ With regards to shipping, UNCLOS address the extent that ships have

privileges to navigate in different areas of the seas, the obligations of states over their ships, and a nation states right to interfere in the navigation of ships in

107. The Regulation of International Shipping, INT'L CHAMBER OF SHIPPING, https://www.icsshipping.org/shipping-facts/safety-and-regulation/the-regulation-of-international-shipping (last visited Jan. 7, 2020) [https://perma.cc/8G46-W33C].

108. Jokioinen, supra note 39.

109. Henrik Ringbom, Flex Collin \& Mika Vijanen, Legalities, in Remote AND AUtonomous SHIPS-THE NEXT STEPS, 35-55, 36 (Rolls-Royce plc., 2016).

110. Id.

111. Id. at 36 .

112. United Nations Convention on the Law of the Sea, Dec. 10, 1982, 1833 U.N.T.S. 397 [hereinafter UNCLOS].

113. Ringbom, Collin, \& Vijanen, supra note 109 , at 36.

114. Id.

115. Id. 
different sea areas. ${ }^{116}$

The Law of the Sea is more accepted than ever before in history. The 'Constitution for the Oceans', UNCLOS is recognized worldwide (167 contracting parties) and is considered customary law with regards to its provisions concerning navigational rights. ${ }^{117}$ UNCLOS provides the rules on the formation and delimitation of maritime zones. UNCLOS lays out states right and obligations in each maritime zone. including detailed rules on states' rights and obligations or each zone. ${ }^{118}$

The first and most important question that needs to be addressed is whether ships without a crew on board are 'ships' or 'vessels' within the meaning of the convention at all. ${ }^{119}$ Ship and vessel are used interchangeably in UNCLOS, but neither is defined. ${ }^{120}$ To determine is if an unmanned vessel would qualify, we must look at the nature of the activities carried out by the large, self-propelled, cargo-carrying, commercially-operated unmanned ships. Due to their size, features and functions they will most likely have to be treated as "ships" or "vessels" under UNCLOS. Presently international conventions that define the term ship do not establish a requirement of a crew. ${ }^{121}$ The definition of a ship is largely void any reference to whether or not the ship is manned. It would also seem that if two ships are preforming similar duties, one manned and the other unmanned, they should not be treated differently by the rules when similar dangers are present.

Unmanned ships would have the same obligations with respect to compliance with international rules. ${ }^{122}$ The inverse would require that unmanned ships would also enjoy the same passage rights as manned ships and cannot be refused access to other states' waters on the basis that they are not crewed. ${ }^{123}$

\section{B. Port and Coastal State Jurisdiction}

A flag state's jurisdiction applies regardless of a ship's location, other states' jurisdiction over the ship depends on the maritime zone in which the ship is located. ${ }^{124}$ As a ship nears the coastal states shore, the state's authority over a foreign ship increases. ${ }^{125}$

The coastal/port state has broad jurisdiction over foreign ships if the ship is

116. Id.

117. $I d$.

118. Id.

119. See generally Robert P. McCleskey, Jr. \& Jeremy A. Herscharft, Unique Features of Maritime Collision Law, 79 Tul. L. REv. 1407 (2005).

120. UNCLOS, supra note 112.

121. Ringbom, Collin \& Vijanen, supra note 109.

122. UNCLOS, supra note 112, at arts. 25(2), 211(3) and 255.

123. Id.

124. Id.

125. Charles Noble Gregory, Jurisdiction over Foreign Ships in Territorial Waters, 2 MicH. L. REV. 333, 350 (1904). 
voluntarily in port or internal waters. ${ }^{126}$ The jurisdiction of the state over foreign ships is complete in internal waters. ${ }^{127}$ Moreover, port states have wide discretion to create conditions of entry on foreign ships who are requesting to access their port. ${ }^{128}$ Therefore, a port state may (unless it has accepted specific obligations to the contrary) deny unmanned ships transit to its ports or internal waters, provided that the refusal adheres to more certain general reasonableness standards that exist in international law, such as non-discrimination, proportionality between the measure and its objective and that the prohibition does not constitute an abuse of right. ${ }^{129}$ This has the potential to be a significant limitation of the free of movement of unmanned ships.

States' rights to limit transit through the state's territorial waters (which may extend up to twelve nautical miles from the coastline/baseline), are more limited. All ships enjoy a right of 'innocent passage' through other states' territorial waters. ${ }^{130}$ An innocent passage is one that is not "prejudicial to the peace, good order or security of the coastal state." ${ }^{\prime 31}$ The criteria used to evaluate innocent passage focuses on the ships' activities such as use or threat of force, military activities, fishing activities or willful and serious pollution. ${ }^{132}$ Under this criteria the ship's manning level or lack thereof would not preclude innocent passage under UNCLOS. . $^{133}$

The coastal state's legislative jurisdiction is regulated under UNCLOS and provides that a state may not impose its national requirements on the construction, design, equipment or manning of foreign ships in its territorial seas, unless those requirements are giving effect to "generally accepted international rules and standards." 134 Independent of the laws that the coastal state has adopted, it may not "impose requirements on foreign ships which have the practical effect of denying or impairing the right of innocent passage." 135 Under UNCLOS the right of innocent passage is granted even to ships that are deemed to pose a particular risk for the coastal state, such as ships carrying inherently dangerous or noxious substances, nuclear-powered ships and ships carrying nuclear material. ${ }^{136}$ It would be highly unlikely that autonomous vessels would be found to pose a greater risk than a vessel carrying dangerous substances. Therefore, port states would not be authorized to deny innocent passage purely because the vessel

126. UNCLOS, supra note 112, at arts. 25(2), 211(3) and 255.

127. Id.

128. Jurisdiction Over Vessels, NAT'L OCEAN AND ATMOSPHeric Admin. OfFice Of Gen. COUNSEL (Mar. 24, 2017), https://www.gc.noaa.gov/gcil_jurisdiction.html [https://perma.cc/H8Q4XKJ5].

129. UNCLOS, supra note 112, at art. 300.

130. Id. at art. 17(3)(a).

131. Id. at art. 19(1).

132. Id. at art. 19 and art. 21.

133. Id. at art. 19(1) and 19(2).

134. Id. at art. 21(2).

135. $I d$. at art. 24(1)(b).

136. Id. at art. 21(2), 24(1)(b), and 23. 
does not have a crew onboard.

A coastal state's enforcement and regulatory authority over vessels transiting its territorial sea are further limited if they form part of a 'strait used for international navigation' and vessels have a stronger right of passage. ${ }^{137}$ Ships in these straights enjoy the enhanced rights of 'transit passage,' where ships' right of continuous and expeditious passage must be allowed and may not even be temporarily suspended by the states. ${ }^{138}$ Many other straits, are governed by international conventions which guarantees the navigational rights of foreign vessels. $^{139}$

The state's jurisdiction to enforce national requirements is increasingly limited when ships are transiting in the exclusive economic zone (EEZ), which may extends from the states' baseline to a maximum distance of $200 \mathrm{~nm} .{ }^{140}$ In this zone ships generally have a right to freedom of navigation, subject to having due regard to the interest of other states. ${ }^{141}$ In the EEZ, coastal states' jurisdiction limited to prescribing rules, mostly for protection of the environment. This excludes interfering in the passage, except for the most toxic forms of pollution. ${ }^{142}$

In seas that are not under the jurisdiction of any coastal state, the high seas, the flag state alone has jurisdiction over the ship. This rule has exemptions, but none would apply specifically to autonomous vessels. ${ }^{143}$

\section{Other Relevant Provisions in UNCLOS}

Aside from the jurisdictional provisions, other UNCLOS regulations may be problematic for unmanned ships. One such obligation requires that each ship has a properly qualified master and a crew. ${ }^{144}$ This mandate could arguably be met in the case of remotely operated vessels by the shore-based operator, it is less clear how a fully automated ship would meet the requirement. Generally accepted international rules may need to be modified depending on which level of autonomy the ship is using. ${ }^{145}$

Under UNCLOS the master has an obligation to render assistance to persons in danger or distress. ${ }^{146}$ This requirement of communication which falls under this duty can presumably be met by remotely operated ships by a relay of radio communications from the shore-based operator. However, the duty to physically

137. Id. at art. 23.

138. Id. at art. $37-44$.

139. Id. at art. $37-44,35(\mathrm{c})$.

140. What is the EEZ?, NAT'L OceAnic AND Atmospheric Admin. (June 25, 2018), https://oceanservice.noaa.gov/facts/eez.html [https://perma.cc/37WW-ADC5].

141. UNCLOS, supra note 112, at art. 58.

142. Id. at art. 211(5), 220.

143. Id.

144. Id. at art. 94(4)(b)

145. Id.

146. Id. at art. 98(1). 
assist would be difficult for a ship without a crew on board. The duties include the limiting language "in so far as he can do so without serious danger to the ship" or "in so far as such action can be reasonably expected of him" which will likely reduce the obligations for unmanned ships. ${ }^{147}$ However, it is not dispositive that the lack of a crew will absolve the vessel of its duty to aid to the extent necessary and reasonable. ${ }^{148}$

\section{Technical Requirements}

The International Maritime Organization adopted more than 50 international conventions and protocols aimed at creating uniform rules for international shipping. ${ }^{149}$ The majority of the rules form obligations imposed on a ship's flag state. ${ }^{150}$ These regulations ensure that each member flag state is complying with the conventions. Flag states conduct inspections of their vessels and issue a certificate proving compliance with the convention. ${ }^{151}$ This certificate is accepted by each member flag state. ${ }^{152}$ This verification by the flag state does not bar the port state from inspecting the vessel to ensure current compliance with the flag states requirements and requiring compliance before departure from port. ${ }^{153}$

It is not possible to explore all of the IMO conventions in this note; therefore, I have chosen to review those conventions that pose the most significant barriers to unmanned vessels. Theses conventions (SOLAS, MARPOL, STCW and COLREGs) are international accepted and apply globally. I will also briefly evaluate the Maritime Labor Convention (MLC), which has been ratified by more than 70 states. $^{154}$

\section{E. The International Convention for the Safety of Life at Sea (SOLAS)}

The main convention for maritime safety is the SOLAS Convention. It's first version adopted in 1914 has 162 contracting states. ${ }^{155}$ Many SOLAS rules are only applicable to ships of a specific classification or age while the applicability

147. Id.

148. Id. at art. 91 .

149. Adopting a convention, Entry into force, Accession, Amendment, Enforcement, Tacit acceptance procedure, INT'L MAR. ORG., http://www.imo.org/en/About/Conventions/Pages/ Home.aspx (last visited Jan. 7, 2020) [https://perma.cc/3TL8-6QBR].

150. Id.

151. International Maritime Organization, Resolution A.1119(3), Procedures for Port State Control, adopted Dec. 6, 2017, at 8 .

152. $I d$.

153. Id.

154. See generally Ratification of MLC Convention, INT'L LABOUR ORG. https://www.ilo.org/ dyn/normlex/en/f?p=NORMLEXPUB:92:0:...:., (last visited Sept. 26, 2019) [https://perma.cc/555RU9Y3].

155. International Convention for the Safety of Life at Sea, Nov. 1, 1970, 32 U.S.T. 47, 1184 U.N.T.S. 278 [hereinafter SOLAS]. 
of others rules depends on the trading area. ${ }^{156}$ The focus here is on SOLAS requirements that would apply to a new bulk carrier above $500 \mathrm{gt}$ commercially used in international trade. This review thus focuses on the requirements that explicitly or implicitly are based on the presence of crew members.

Chapter I establishes the application of the regulations in the Annex and an exemptions scheme, which is based on three different categories of exemptions:

1. Certain categories of ships that are completely exempt from the SOLAS rules and beyond its scope are listed in Regulation 3. None of these listed categories are applicable to unmanned vessels. ${ }^{157}$

2. Regulation 4(b) includes a possibility for flag state administration to exempt "any ship which embodies features of a novel kind" from the requirements of Chapters II-1, II-2, III and IV if their enforcement "might seriously impede research into the development of such features."158 If these exemptions are granted the IMO must be given notice and these exemptions do not relieve the ship from the responsibility to comply with safety requirements that the administration deems are sufficient for the service and granted by the port states. ${ }^{159}$

3. The general possibility of flag states administrations to authorize deviations if the deviation is equally as safe and effective as the requirement of the Convention. ${ }^{160}$

Generally, the third exception applies where SOLAS requires "that a particular fitting, material, appliance or apparatus, or type thereof, shall be fitted or carried in a ship, or that any particular provision shall be made." ${ }^{161}$ In cases such as these, the administration may allow other solutions "if it is satisfied by trial thereof or otherwise that such fitting, material, appliance or apparatus, or type thereof, or provision, is at least as effective as that required by the present regulations." 162 Notification is required to the IMO along with a report of any trials made. ${ }^{163}$ SOLAS contains the mandates for ships in the areas of structure, stability, machinery and electrical installations, fire protection, and life-saving appliances. ${ }^{164}$ These chapters do not raise any issues unique to autonomous vessels as they mainly cover construction, equipment and materials on board. ${ }^{165}$ Unmanned vessels would still be required to meet the obligations of the ships class. For example, if the SOLAS regulations require that a ship is constructed to meet certain stability requirements or features such as double halls, autonomous vessels would have the same requirement.

156. Id. at ch. I.

157. Id. at ch. I-3.

158. Id. at ch. I-4.

159. Id.

160. Id.

161. Id. at ch.I-4.

162. Id.

163. Id.

164. Id. at ch. II-1, II-2, III.

165. Id. 
However, unmanned ships would have difficulty complying with some operational requirements, mainly relating to information procedures and communication for the crew, alarms, and monitoring mechanisms. ${ }^{166}$ To comply, it is likely that the monitoring equipment, and system operation may have to be shifted or added to the shore-based communications center. Under this transfer, the term 'navigating bridge' would need to be understood to mean the operations center where the ship is controlled. As technology advances, many of the provisions specifically address the ability to replace human monitoring by technical equipment. ${ }^{167}$

If the flag state plays a proactive and supportive role it is possible for exemptions and modifications to the 'navigation bridge' and communications systems to be considered compliant even though they are not onboard the vessel. ${ }^{168}$

Chapter IV regulates radio communication and includes the requirements of the equipment as well as watch-keeping requirements for the crew. ${ }^{169}$ The functional requirement mandates is that while a ship is at sea she must be capable of transmitting a distress alert by at least two separate independent means, receiving distress alerts, transmitting and receiving in distress situations, and communicating maritime safety information, general radio communication and bridge-to- bridge communications. ${ }^{170}$ The ability to gain an exception to these requirements is limited. ${ }^{171}$ Compliance with these rules by unmanned ships would have to ensure that radio communication can be relayed to the shore based command center and be actively monitored by the ship's operator along with the ships current position. ${ }^{172}$

Chapter $\mathrm{V}$ contains rules on manning of ships, voyage planning, bridge visibility requirements and pilot transfer arrangements, some of which may pose a substantial barrier to unmanned vessels. ${ }^{173}$ It also lays out the obligation for masters to assistance those in distress and provides the master's wide discretion in decision-making relating to safety at sea or environmental protection, which cannot be overridden by the owner, charterer or operating company. ${ }^{174}$ Chapter V's rules also have a wider applicability, with regards to the size of ships and trading areas, than the other SOLAS chapters. The scope for exemptions and equivalences are also more restrictive than other SOLAS regulation. ${ }^{175}$

The rules concerning manning of ships are of particular importance. The decisions regarding safe manning levels are administered by the flag state, once

166. Id.

167. Id. at ch. II.

168. Id.

169. Id. at ch. IV.

170. Id.

171. Id.

172. Id. at ch. IV.

173. Id. at ch. V, Reg. 14, 22, 23.

174. Id. at ch. V, Reg. 33, 34-1.

175. Id. at ch. $\mathrm{V}$. 
the flag state's requirements are satisfied they issue a safe manning document to the ship. ${ }^{176}$ SOLAS Regulation V/14 only requires that "from the point of view of safety of life at sea, all ships shall be sufficiently and efficiently manned."177 Further guidelines (IMO Resolution A.1047(27)) provide a more detailed and broader range of goals regarding manning, security, safety, cargo and environmental protection, however they are not legally binding. ${ }^{178}$

The pivotal question is whether a safe manning document could be issued to an unmanned vessel. Another question that arises is whether a shore-based operator or the ship's onboard control system can assume the duties of a traditional crew for the purposes of the safe manning document.

This determination would require that a national administration declare that a shore-based operations center can ensure the safe operations of unmanned vessels. The guidelines on safe manning specifically provide that technical equipment and the level of automation is to be taken into consideration when determining safe manning requirements. ${ }^{179}$ It is commonly believed that the operation of the ship will actually become safer as new types of technology and redundancy systems are brought onboard and new functions will be performed from ashore. ${ }^{180}$

However, the precise wording of the individual provisions should be considered with some skepticism, as the international and national rules on safe manning were drafted on the foundation that the crew is based on board the ship. Unmanned ships were not contemplated at the time the rules were developed and we should avoid reading the text to support the development of unmanned vessels. This cautious view is heightened for fully autonomous operations, which stretches the notion of manning even further.

Chapter VI provides operational requirements related to the safe loading and unloading of solid bulk cargoes. ${ }^{181}$ Including loading procedures and requirements which anticipate active communication between the master, the shipper, and the terminal operator. ${ }^{182}$ This responsibility could be transferred to a shore-based agent that would be present during cargo operations to bring autonomous vessels into compliance with the rule.

Chapter IX requires a safety management system to be established by the shipowner or any person who has assumed responsibility for the ship. ${ }^{183}$ The ISM

176. Id. at ch. V, Reg. 14.

177. Id.

178. Id. at Reg. V/114; International Maritime Organization, supra note 151, at Resolution A.1047(27).

179. International Maritime Organization, supra note 151, at Annex 2 ฯ 1 1.1.3, 1.1.4.

180. Saarni, Nordberg-Davies \& Hakkonen, supra note 10, at 23.

181. SOLAS, supra note 155 , at $\mathrm{Ch}$. V.

182. Directive 2001/96/EC of the European Parliament and of the Counsel of 4 December 2001 Establishing Harmonized Requirements and Procedures for the Safe Loading and Unloading of Bulk Carriers, 2001 O.J. (L 13); International Maritime Organization, supra note 151, at Res. 862(20).

183. SOLAS, supra note 155 , at ch. V. 
Code's goal is to achieve greater involvement of the parent company and shipowner in the safety management of individual ships. It provides for the responsibilities of the master, plans for shipboard operations, maintenance, emergency preparedness, and required documentation. ${ }^{184}$

In the case where manning levels are reduced to zero, even though the link between shore-based operators and the ship are strengthened the compliance code poses challenges. ${ }^{185}$ Chapter IX provides for no deviations, except for government-operated ships used for non-commercial purposes. ${ }^{186}$

Chapter XI-2 proscribes enhance maritime security. ${ }^{187}$ This chapter is mainly concerned with obligations for flag state administrations and parent companies, but presumes a strong communication link between them and the ship. ${ }^{188}$ Regulations 11 and 12 specifically provide for the possibility for states parties to agree on alternative security agreements with other states or equivalent arrangements for their own ships so long as they are at least as effective as those provided in Chapter XI-2. ${ }^{189}$

\section{F. International Convention for the Prevention of Pollution from Ships}

MARPOL is the main IMO convention for addressing various forms of pollution from ships. ${ }^{190}$ It includes construction and equipment provisions for ships, operational and procedural requirements, including discharge limits, procedures for ship-to-ship transfers, reporting obligations in case of accidental discharge, and requirements to keep record books. ${ }^{191}$ Unmanned ships will have to adhere to these requirements, but generally speaking the MARPOL requirements are unlikely to present challenges in this regard. Record books would likely be maintained in an electronic form at the operations center, while reporting and notification obligations exist in several conventions and need to be addressed. One possible solution would be shifting the responsibility of reporting to the shore-based operator, or the automatic reporting of any incidents of pollution by the ship's onboard control system.

\section{G. Convention on the International Regulation for Preventing Collisions at Sea (COLREGs)}

The COLREGs prescribe the 'rules for the road' for shipping operations, including safe speed, signals, lights, and the vessel hierarchy for the maneuvering

184. Id. at ch. IX.

185. Id.

186. Id. at ch. IX; SOLAS non-commercial purposes.

187. Id. at ch. XI-2.

188. SOLAS, supra note 155.

189. Id. at ch. IX, regulations 11 and 12 .

190. International Convention for the Prevention of Pollution from Ships (1973) as modified by Protocol of 1978 .

191. Id. at Annex I, II, III, IV, V,VI. 
of different types of vessels in different situations. ${ }^{192}$ Under the current COLREGs unmanned ships represent no special category and would be required to follow the rule applicable to their designation. ${ }^{193}$

The COLREGs cover both the navigational tasks of the crew on board a ship such as situation awareness (including lookouts) and operational decision-making with regards to collision avoidance, priorities, and speed. It is likely that both the navigational and decision-making requirements would pose challenging for unmanned ships. ${ }^{194}$

The look-out requirement provides that "[e]very vessel shall at all times maintain a proper look-out by sight and hearing as well as by all available means appropriate in the prevailing circumstances and conditions so as to make a full appraisal of the situation and of the risk of collision."195

The purpose of the lookout rule is to make sure that the Conning Officer is aware of objects around them and enables them to make informed decisions with respect to actions in collision avoidance. ${ }^{196}$ The Rules do not necessarily require that a lookout be a person, but rather address the systematic collection of information. The use of the words "proper" and "appropriate" provide flexibility for how such a lookout is organized on board.

The pivotal question for unmanned ships is whether the wording and interpretation of Rule 5 is expansive enough to accept a combination of cameras, radars, audio technology and other technical solutions, to replace a human lookout. ${ }^{197}$ With regards to the purpose of the rule and its flexible wording, it is arguable that unmanned ships would comply if their equipment allows the controller to have an overview of the circumstances allowing him take action within the appropriate response time to the same extent or better than if he were on board. Due to the nature of collision avoidance regulations, any such acceptance should be done at an international level rather than by individual states. ${ }^{198}$

Another relevant question is whether the shore-based operator could also assume control of the operational decisions of the ship's navigation and maneuvering. COLREGs do not pose any direct textual barriers. Steering and sailing rules are regulations on the 'vessels', without reference to the person making the decisions. ${ }^{199}$ The more difficult question arises when operational decisions are automated by the vessel alone without the shore-based operator. The shipboard operating system could be programmed with algorithms that comply

192. Convention on the International Regulations for Preventing Collisions at Sea, Nov. 20, 1972, 28 U.S.T. 3459, 1050 U.N.T.S. 16 [hereinafter COLREGs].

193. Id.

194. Id.

195. Id. at Rule 5.

196. Saarni, Nordberg-Davies \& Hakkonen, supra note 10, at 24.

197. See generally Levander, supra note 1 .

198. Christopher B. Llana \& George P. Wisneskey Handbook of the Nautical Rules OF THE ROAD, (3d ed. 2006) (ebook).

199. COLREGs, supra note 192. 
with the steering and sailing rules of COLREGs, even anticipating the actions of other ships. ${ }^{200}$ The rules for preventing collisions includes obligations for both vessels to take avoidance action if it seems that there is a risk of collision. ${ }^{201} \mathrm{In}$ addition, the COLREGs include a rule which gives precedence to good seamanship over a formalist rule. ${ }^{202}$ Good seamanship for this purpose is a matter of fact to be determined after the evaluation of all relevant prevailing circumstances. It would pose a challenge to create an algorithm that prioritizes 'good seamanship' over a clear rule into the automated system. ${ }^{203}$

Another uncertainty in the COLREGs is whether unmanned ships would be given a specific signal, light, or AIS message, to inform mariners on board other ships about their unmanned status. It is likely that unmanned vessels would require this special designation to alert other mariners, and although some national solutions could be justified under Rule 1(b), a designation decision should be made at international level. ${ }^{204}$ On the other hand, if the goal is for unmanned ships to be naturally integrated into the fleet, unmanned ships should not have a designation that would offer it special priorities over other ships in COLREGs. ${ }^{205}$

\section{H. International Convention on Standards of Training, Certification and Watchkeeping for Seafarers (STCW)}

The STCW Convention does not in a purely textual context apply to persons who are controlling a ship from the shore but is applicable "to seafarers serving on board seagoing ships" flying the flag of a state party. ${ }^{206}$

Though not strictly applicable, an intensive training regime will have to be developed for persons operating ships from the shore-based operations center. In the interim, national administrations have some discretion to apply equivalent arrangements, including allowing for technical developments. Under Article $\operatorname{IX}(1)$ :

200. $I d$.

201. Id.

202. Id.

203. COLREGs, supra note 192, r. 2 provides that: (a) Nothing in these Rules shall exonerate any vessel, or the owner, master or crew thereof, from the consequences of any neglect to comply with these Rules or of the neglect of any precaution which may be required by the ordinary practice of seamen, or by the special circumstances of the case. (b) In construing and complying with these Rules due regard shall be had to all dangers of navigation and collision and to any special circumstances, including the limitations of the vessels involved, which may make a departure from these Rules necessary to avoid immediate danger.

204. COLREGs, supra note 192, at r. 1(b).

205. Compliance with the COLREGs might be ensured merely by treating unmanned ships as a vessel "not under command" or "restricted in her ability to maneuver" under r.18, which would require other ships to give way.

206. International Maritime Organization, International Convention on Standards of Training, Certification and Watchkeeping for Seafarers (Jul. 7, 1978) [hereinafter STCW]. 
The Convention shall not prevent an Administration from retaining or adopting other educational and training arrangements, including those involving seagoing service and shipboard organization especially adapted to technical developments and to special types of ships and trades, provided that the level of seagoing service, knowledge and efficiency as regards navigational and technical handling of ship and cargo ensures a degree of safety at sea and has a preventive effect as regards pollution at least equivalent to the requirements of the Convention. ${ }^{207}$

Shore-based operators training in maritime and technology skills along with their required competencies will need to be given consideration under the STCW. Until this is achieved there is nothing barring application of the STCW and other national requirements in the same manner as if the persons were on board the ship. If and when it is concluded that shore-based operators require particular training, the relevant provisions of the STCW should be amended to reflect the new requirements for the operation of unmanned or automated ships.

A largest hurdle lies in the STCW's standards for watchkeeping. The STCW states "that a safe continuous watch or watches appropriate to the prevailing and conditions are maintained on all seagoing ships at all times." ${ }^{208}$ On manned vessels this standard is met by the master, chief engineer, and watchkeeping personnel. This regulation states that "officers in charge of the navigational watch are responsible for navigating the ship safely during their periods of duty, when they shall be physically present on the navigating bridge or in a directly associated location such as the chartroom or bridge control room at all times."209

The mandatory STCW code provides detailed provisions for watchkeeping standards for the lookouts, bridge, engine room and radio watch personnel in various conditions. ${ }^{210}$ The STCW also limits working hours, as well as voyage planning tasks which are to be completed before the vessel gets underway. ${ }^{211}$

Before autonomous vessels can commercially operate without crews, or even with drastically reduced crews, the STCW watchkeeping requirements will have to be amended. It is important to keep in mind that tasks normally preformed onboard crewed vessel will be taken over by either the on shore-operator or the onboard control system. The delegation of these tasks to shore, or by the ship herself, will strike at the heart of the regulations, in that it will reduce crew fatigue that is associated with minimally manned vessels.

In the end, the decision of whether a particular use of manning, such as a shore-based operator in conjunction with onboard technology will satisfy the requirement for maintaining a safe lookout and watchkeeping on the ship will need to be addressed through an amendment or supplement to the STCW code.

207. Id. at art. $\mathrm{IX}(1)$.

208. Id. at Reg. VIII/2 § (1).

209. Id. at Reg. VIII/2 § (2).

210. Id. at Reg VIII.

211. Id. Section A-VII/1. 


\section{Maritime Labour Convention (MLC)}

The primary convention in the field of maritime employment is the 2006 Maritime Labour Convention (MLC). It applies to all seafarers on ships "ordinarily engaged in commercial activities." 12 The MLC regulates labour conditions on board vessels, conditions of employment, fundamental rights of seafarers and requirements for recreational facilities on board.

With respect to unmanned ships the scope of the MLC Convention is limited to 'seafarers,' which is defined as "any person who is employed or engaged or works in any capacity on board a ship to which this Convention applies." ${ }^{213}$ From a textual standpoint, a ship which is entirely unmanned is not subject to these rules. However, for unmanned ships it might not be that simple, as Article II(3) includes a specific requirement for examining whether a particular category of person is to be considered as a seafarer: ${ }^{214}$ In the event of doubt as to whether any categories of persons are to be regarded as seafarers for the purpose of this Convention, the question shall be determined by the competent authority in each Member after consultation with the shipowners' and seafarers' organizations concerned with this question. ${ }^{215}$

Since MLC regulations deal largely with living and working conditions on board ships their provisions would not inherently apply to unmanned vessels. The employment conditions and working hours of shore-based operators will likely be regulated under a land-based equivalent to the MLC, which considers the unique tasks operators preform.

\section{J. Maritime Liability Rules}

Maritime liability rules provide a unique scheme to address shipowners' liabilities and compensation for damages. These rules have been applied for centuries, and account for the hazards of the shipping industry. Over time international conventions have led to accepted practices concerning liability issues such as who is responsible, on what basis, and for what amount. These practices are not as widely accepted as safety conventions and can depend on national traditions and which legal system is adjudicating the case. The choice of law question for these cases depends on multiple factors, such as where the incident took place, the type of incidents, and under certain circumstances on the nationality of the key players involved, including the ship's flag state. ${ }^{216}$

When addressing who is liable under maritime rules, the general principle is

212. Maritime Labor Organization, Maritime Labour Convention, art. $2 \S 4$ (2006).

213. Id. at art. II $\S(1)(\mathrm{f})$.

214. Id. at art. II $\S(2)$ and art. II $\S(3)$.

215. Id. at art. II $\S(3)$.

216. See generally Graydon S. Staring, Contribution and Division of Damages in Admiralty and Maritime Cases, 45 UCLA L. REV. 304-345 (1957). 
that the owner rather than the master or crew is held to answer for damages. ${ }^{217} \mathrm{~A}$ broad vicarious liability scheme has been designed to hold the owners/operator of the vessel accountable for fault or negligence rather than master, crew, pilot, or other seafarers in service of the ship. ${ }^{218}$ While the availability of recourse for third parties against individuals responsible for injuries is very limited, the owner of the vessel may have a cause of action for negligence against an individual for fault who was in the ship's service. ${ }^{219}$ In cases such as this, special liability rules have been established, but they do not alter the per se vicarious liability of the owner. Where the cause of action arises out of a collision at sea, liability is placed on the $\operatorname{ship}(\mathrm{s})$ at fault, without regards to the individuals responsible for the collision. ${ }^{220}$ Where a claim arises out of environmental harm, liability is placed on the registered owner of the vessel. ${ }^{221}$ As long as the resulting injury can be linked to the operation of the vessel, the actions or lack thereof by the crew will have no bearing on the question of liability. ${ }^{222}$

Differing degrees of fault or negligence are required for liability depending on the incident. ${ }^{223}$ In instances of environmental pollution or where passengers of the vessel have been injured, there is no requirement to prove negligence. In these cases, the owner is strictly liable for the harm or injury. ${ }^{224}$ In other cases where strict liability is not assessed, the owner is considered to be negligent per se for the actions of his employees. In cause arising from collisions, fault-based liability is also the sole rule for apportioning liability. ${ }^{225}$ Autonomous ship operations may introduce new considerations regarding fault. ${ }^{226}$

To counter the heavy presumption of per se negligence, maritime law provides the owner with the right to limit their financial liability. ${ }^{227}$ This right of shipowners to limit liability is only lost in very exceptional cases. ${ }^{228}$ Under this right, full recovery by the injured party may not be possible due the capping of damages. ${ }^{22}$ This limitation on liability covers faults of the crew and those

217. Id.

218. Saarni, Nordberg-Davies \& Hakkonen, supra note 10, at 23.

219. Mary Winggrove, Autonomous Ships Will Need Major Insurance Changes, MARINE ELECTRONiCs \& COMMUNiCATIONS (Sept. 12, 2017), http:/www.marinemec.com/news/ view,autonomous-ships-will-need-major-insurance-changes_49132.htm [https://perma.cc/ZXN6GRF3].

220. Id.

221. Id.

222. Dennis J. Stone, The Limitation of Liability Act: Time to Abandon Ship?, 32 J. MAR. L. Cом. 317, 328 (2001).

223. Id.

224. Id.

225. Id.

226. Chris Reed et al., Research Paper, Responsibility, Autonomy and Accountability: legal liability for machine learning, 243 QUEEN MARY U. LONDON SCH. L. 1, 31 (2016).

227. Id.

228. $I d$.

229. Stone, supra note 222. 
assisting in the operation of the ship, and therefore has broad application. ${ }^{230}$

The fundamental function of the general maritime liability regime is to place vicarious liability on the owner/operator of the ship, and to in turn provide the owner with a strong right of limiting such liability. These rules also form the basis for liability insurances and other risk management tools.

Though there is not an immediate need to change the foundations of maritime liability for autonomous ships, it is important to realize that the technical developments and increased automation will challenge the current liability framework.

While errors committed by shore-based operators who are controlling ships will most likely be treated in the same way as errors committed by on-board crew members, autonomous technology may generate new types of errors and causal relationships. A new issue that will need to be addressed is damage caused by the malfunction of an autonomous system, by device failure or faulty software. Under a failure of this sort, the owner/operator would probably be liable, at least in part, if he or the shore-based operator fail to override the autonomous system. More complicated would be scenarios where human intervention is not possible. For example, when the vessel is exclusively using the automated system due to a loss of connectivity. If a maritime incident then occurs due to either a failure in the autonomous system or because of programming errors, it is less obvious that the owner/operator would carry the liability under a strictly fault-based liability scheme. This raises the question of the responsibility of the systems manufacturer with regards to fault and damages.

Negative outcomes for autonomous vessels under a fault-based liability scheme may advance the argument in favor of a strict liability regime for automated ships. The creation of a strict liability standard for autonomous vessels would treat them significantly different from their manned counter parts, which may not be justified from a risk prospective.

As an alternative, those suffering damages may root their claims in other liability systems. ${ }^{231}$ If defective autonomous systems are the cause of an accident, the injured parties could make claims against the builder of the vessel, the manufacturer of the autonomous system, its software, and/or whomever is responsible for maintaining and updating the system. ${ }^{232}$ This would fill the liability gap and shift claims from falling under the admiralty scheme to products liability actions. ${ }^{233}$ This evolution could provide better outcomes for those injured as many product liability schemes are based on a strict liability of the producer and does not include a general financial limitation of liability. ${ }^{234}$

230. $I d$.

231. Tuan Kee Lee, Note, Liability of Autonomous Ship: The Scandinavian Perspective, SCANDINAVIAN InST. MAR. L. 1, 28 (2016).

232. Autonomous Ships-Zooming in on Liability and Insurance, INSURANCE MARINE News (Dec. 13, 2018), https://insurancemarinenews.com/insurance-marine-news/autonomous-shipszooming-in-on-liability-and-insurance/ [https://perma.cc/RG6Z-X8M8].

233. See generallyid.

234. Reed et al., supra note 226. 
If the existing maritime liability regime is insufficient to cover the concerns of business partners, claimants and the general public relating to the risks involved with autonomous shipping, pressures for an alternative solution will grow. Autonomous shipping as well as autonomous vehicles may become a catalyst for this development, as it is easier to assign fault through product liability in systems where there is no human intervention involved. ${ }^{235}$

The application of product liability rules to autonomous shipping is by no means straightforward. The EU Directive on the matter, for example, limits the types of damages that are recoverable. ${ }^{236}$ It is likely that product and other liability rules will operate simultaneously with the traditional maritime liability regime in the future and the prospect of several bases of liability for autonomous shipping will require a detailed and systematic review prior to the normalized use of autonomous ships. ${ }^{237}$ The shifting to a parallel liability regime or supplementary system involves complex legal questions relating to scope and priorities. $^{238}$

The demand for changing rules for autonomous shipping is not as pressing in maritime liability as it is in the IMO Conventions, but these ships will significantly affect the framework of maritime liability. Autonomous shipping could contribute to the introduction of new legal regimes to supplement or parallel the traditional maritime law framework. As automation increases, there will be a growing need to trust in the systems, and also in the legal regime for remedies, therefore it is critical that a reliable system with predictable results is established.

Risk management will be affected more generally by the increases in automation. Maritime insurance and contracts are currently drafted under the premise that ships are manned. With the introduction of autonomous ships, the roles, responsibilities and liabilities for stakeholders will change, requiring adjustments in insurance. As risk factors vary, it should be expected to see a wide variety of premiums between manned and autonomous ships. The legal implications of autonomous shipping accordingly extend beyond the liability rules.

\section{IMPLICATIONS OF MARITIME LAW AND RECOMMENDATION FOR AUTONOMOUS SHIPS}

The existing frameworks of maritime law does not contemplate unmanned ships. A broad range of rules are potentially concerned with the introduction of unmanned shipping operations, the nature of the challenges to accommodate this shift in the existing law differs from one type of rule to another.

235. Id.

236. Id.

237. Id.

238. Id. 


\section{A. Seaworthiness}

The largest barrier for autonomous ship to overcome is the lack of any human presence on the ship. International and domestic law requires safe manning levels, not only for safety at sea but also to determine if a ship is seaworthy.

For a ship to be considered seaworthy it must be properly manned. ${ }^{239}$ In Hong Kong Fir Shipping v. Kawasaki Kisen Kaisah the court stated that an insufficient and/or incompetent crew can cause a vessel to be unseaworthy. ${ }^{240}$ Under this precedent the fact that autonomous ships have no crew onboard could render them unseaworthy.

However, it could be argued that the competence of the crew rather than the number of crew members determines if the ship is deemed seaworthy. If applying this reasoning, as long as the shore-based operator is deemed to be competent to ensure the safe navigation of the vessel, a safe manning level could theoretically be one citing the shore-based operator as a crew member. This interpretation would remove this barrier, allowing for autonomous vessels to be considered seaworthy.

If the seaworthiness requirement cannot be satisfied it would have grave effects on the ability of autonomous vessels to operate. The unseaworthiness of a vessel exposes shipowners to cargo claims by denying the benefits of the Hague and Hague-Visby Rules which provide exceptions to liability for cargo damage. ${ }^{241}$

UNCLOS manning requires, that a flag state must take steps to ensure safety at sea, including measures to ensure its vessels have crews that are appropriate in numbers and qualifications. ${ }^{242}$ SOLAS has a similar requirement that a ship must be sufficiently and efficiently manned. ${ }^{243}$

Under both UNCLOS and SOLAS safe manning levels are considered to be subjective, and jurisdictions have wide discretion as to the adequate numbers. As an example, the United Kingdom requires shipowners to submit proposals for safe manning to the Secretary of State dependent on the type of vessel and nature of the voyage. ${ }^{244}$ Therefore, the owner of an autonomous vessel could submit a proposal with a safe manning level of zero or cite to the shore-based operator and apply with a safe manning level of one.

The lack of a crew onboard creates another problem when it comes to the rules of the road which are formalized in the COLREGs. The International Regulations for Preventing Collisions at Sea apply to all seagoing vessels that are used or capable of being used as a means of transportation on the water. ${ }^{245}$ These regulations would apply to autonomous vessels used for transporting cargo on seagoing voyages.

239. Hague-Visby Rules, art. $3 \S 1$ (b), Feb. 23, 1968, Stat. 1207, 1412 U.N.T.S. 127.

240. Hong Kong Fir Shipping v. Kawasaki Kisen Kaisah, 2 WLR 474 (1962).

241. Hague-Visby Rules, art. III(1)(b).

242. UNCLOS, supra note 112, at art. 94(4)(b).

243. SOLAS, supra note 155, at ch. 5 Reg 13.

244. Merchant Shipping Regulation No. 782/2015, Reg. 46 (UK).

245. COLREGS, supra note 192, at Rule $3 \S$ A. 
Rule 2(a) places the responsibility to comply with the rules on the vessel, owner, master or crew. ${ }^{246}$ The uses of 'or' arguably allows responsibility to be placed solely upon the vessel although the COLREGs assumes that a vessel has a crew on board and this presents a difficulty for autonomous vessels.

COLREGs rule 5 places a duty on the vessel to maintain a proper lookout by sight and hearing as well as by all available means appropriate in the prevailing circumstances. ${ }^{247}$ It is unclear whether this rule requires a physical presence on the vessel. It could be argued that a shore-based operator could fulfill this requirement with the aid of video and audio feeds from the vessel.

One possible solution to the manning requirement is to treat autonomous ships as being 'not under command.' The characterization under COLREGs rule 3 would require other vessels to give way to autonomous ships, thus giving the ship a navigational right of way. ${ }^{248}$ Courts have interpreted a vessel to be not under command when the ship has lost her ability to be controlled through some failure of equipment or damage rather than the lack of a crew. ${ }^{249}$

It is unlikely that an autonomous ship that possess the ability to navigate would be considered to be not under command. This designation should be reserved for autonomous vessels that suffer a loss of communication with its shore-based operator or when she is in a situation where she is unable to maneuver safety.

Another option under COLREGs is to classify autonomous vessels as 'restricted in her ability to maneuver.' This would require other vessels, except for those not under command to give way to the autonomous vessel. This designation will be largely dependent on the level of autonomy the vessel is using and the nature of her work. Under rule $3(\mathrm{~g})$ vessels which are restricted in their ability to maneuver are traditionally defined as those engaged in dredging, launching and recovering aircraft, mine clearing or towing operations. ${ }^{25}$ Therefore, under the current rule if the autonomous vessel is not engaged in any of these operations she will be given the highest level of responsibility of a power-drive vessel under the COLREGs hierarchy. ${ }^{251}$

In any case, law must adapt with new technology. As the COLREGs currently stand, autonomous ships would not comply. However, this is not an insurmountable barrier. The COLREGs can be, and have been, readily updated by the IMO as new technologies have been introduced to the maritime market. ${ }^{252}$

Rather than bending the rules to suit autonomous ships, a separate annex to the COLREGs should be considered. Alternatively, autonomous vessels could be

246. Id. at Rule 2 .

247. Id. at Rule 5.

248. Id. at Rule 3.

249. The Phoebus, 70 F. Supp. 817 (S.D.N.Y. 1946) (citing Owners of Mendip Range v. Radcliffe, 6 LI.L.R. 375).

250. COLREGS, supra note 192, at Rule $3 \S \mathrm{G}$.

251. Id.

252. A.N. CockCroft \& J.N.F. LAmeijer, A Guild to the Collision Avoidance Rules 137 (7th ed. 2012). 
added to the class of vessel who are restricted in her ability to maneuver. Or the rules could be also be amended to read that 'every manned vessel shall maintain a proper lookout by sight and hearing,' thus relieving autonomous vessels from this requirement. However, another standard, by way of an amendment will need to be devised for autonomous vessels.

\section{B. Liability}

Another question which presents itself with regards to autonomous ships will be the question of liability for marine incidents. As autonomous vessels are introduced into the navigational realm we will need to address whether we will hold them to the same standards as manned vessels.

With regards to liability comes the question of how we will treat collisions between autonomous vessels and manned vessels. As technology develops and advances, autonomous vessels will become safer than manned vessels. It would be logical under the circumstances to assign per se liability to a manned vessel in the case of a collision with an autonomous vessel once the technology has been proven reliable.

On the other hand, we could also assign no per se liability and treat each collision as we currently do and giving no deference to whether the vessels are manned or autonomous. In this case it can be presumed that autonomous vessels will be able to produce more evidence relating to the collision because it will have the data that was transmitted and saved at the shore-based command center. This would aid in assigning liability to the parties, making a per se liability scheme largely unneeded.

New liability schemes for autonomous vessels will have long reaching effects on maritime and product liability insurance which will need to be resolved. The question of to what level the manufacturer will be held liable will need to be addressed. The maritime industry could draw on developments from the autonomous vehicle industry in determining this issue. It is foreseeable that the manufacturers of autonomous vessels will need to carry large product liability coverage given the great financial repercussions of a collision or allision. One solution that has been proposed by the autonomous vehicle industry is a pool consisting of suppliers and manufactures that all pay into the pool based on their risk profiles. Any product liability damages that are award would then be funded from the pool. ${ }^{253}$ This effectively spreads the risk to manufacturers and suppliers which allows them to continue to operate and advance autonomous technology, thus making it safer.

Once autonomous vessels become more prevalent in the maritime industry, we will also have to deal with a shift in the maritime insurance market. We will see a decrease in the premiums to insure autonomous vessels because they will be safer, not being subjected to human error which currently accounts for most

253. Christine K. Kogut, Manufacturers of Autonomous vehicles should be making a SPLASh to Manage Risk, MiLliman (Aug. 2016), http://www.milliman.com/uploadedFiles/insight/ 2016/2277PCP_20160826.pdf [https://perma.cc/M8UA-SQH3]. 
insurance claims. Autonomous vessels will only require coverage when the vessel is being remotely operated. This will likely result in an increase in the insurance rates for manned vessel, which will continue to operate. This will pose a great risk to the maritime shipping industry that would likely result in fewer shippers being able to operate their manned vessel, nor afford autonomous vessels.

One solution to this would be for flag states to offer subsidies to the owners and operators of manned vessels. These subsidies could take three forms, one would be to offset the increased cost of insurance. The second would be to retrofit manned vessels with technology that would allow them to operate as autonomous vessels. The third would be to offer tax incentives for the purchase of autonomous vessels in order to replace manned vessels that are not suitable platforms for retrofitting.

Another solution would be for the flag state to become the insurer for manned vessels to stabilize the market and allow owners to continue to operate. This could be accomplished similarly to how the United States Government operates its flood insurance program. Manned ships would purchase their insurance directly from the flag state when they register and would maintain that coverage as long as they continue to be under that flag state.

This solution could bring with it a host of new issues, such as, more frequent flag state inspections and restrictions due to the fact that the flag state is now also the insurer. It would also pose an obstacle for flag states that cannot afford to insure the vessels registered to them. Further, it would create a scheme of flag state shopping, which to some extent already exists with regards to regulations, and the stability of the flag state, but the rates and requirements of flag states would further add to where owners choose to register.

\section{The Master}

The legal definitions of a master vary according to jurisdiction, but all contain the following elements:

1. A natural person who;

2. Is responsible for a vessel

3. And all things and persons in it and is

4. Responsible for enforcing the maritime laws of the flag state. ${ }^{254}$

In the United Kingdom, a "master includes every person having command or charge of a ship." 255 This definition is broad enough to encompass anyone who is able to control the ship's movements or is responsible for the ship's navigation to be considered a master. Given the duty of the shore-based operator to navigate the ship safety, they will fall under this definition of master.

However, the historic role of the master is much broader than just navigation. The master has legal duties and responsibilities under international conventions, which are enacted through the domestic laws of the flag state and the laws of the port state where the ship docks, as well as private law.

254. John A Carter et Al., The International Law of the Shipmaster 86 (2009).

255. Merchant Shipping Act of 1995 c. 21, § 313, sch. 1 (Eng.). 
It would be impossible for the shore-based operator to fulfill the duties that are imposed on an onboard master such as the duty to render assistance. Under UNCLOS the master is required to assist if it will not endanger their ship, passengers, cargo, or crew. ${ }^{256}$ A shore-based operator would presumably be able to assist in certain situations such as relaying maritime emergencies to authorities, and fire suppression if the vessel was equipped with fire cannons. However, they would not be able to assist in recovering people from the water.

In the maritime community the duty to render assistance is just as much a moral obligation as a legal one. It would be difficult to argue that stakeholders benefiting from autonomous ships can be exempt from this duty. To overcome this, it would be advisable for autonomous ships to have lifeboats containing medical supplies, food, water, and communications devices that can be jettisoned to assist those in peril until they can be rescued.

The master of manned vessels also serves as the ship's agent. This duty requires him to conduct cargo inspections, sign bills of lading, reject or accept dangerous cargo, and maintain legal documents. A shore-based operator cannot assume these responsibilities, therefore autonomous ship owners will have to develop a new system to assume the responsibilities that fall to the master on manned vessels. One way to accomplish this would be to maintain a shore agent who would be present while cargo operations are taking place and to have the authority traditional granted to the master.

\section{Pilotage}

Pilots have guided ships in and out of port by providing local knowledge for centuries. A pilot is defined as any person not belonging to a ship who has conduct thereof ${ }^{257}$ However, even when a pilot has control of the ship the master remains in command of the ship. This means that when an autonomous vessel is entering or leaving port the shore-based operator will either take remote operation of the vessel or increase supervision. The largest obstacle to this assumption is whether port authorities will allow autonomous ships to berth remotely.

Most ports in the world impose compulsory pilotage areas. While detailed pilotage laws vary depending on the jurisdiction there are some legal principles that universally apply. This includes the fact that the duty of a licensed pilot is to provide information and advice while on the vessel to the master in compulsory pilotage areas. ${ }^{258}$ Under compulsory pilotage the shipowner remains vicariously liable for actions of the pilot. ${ }^{259}$

Pilotage creates a number of issues for autonomous vessels. First, pilotage commences once the pilot is on board. ${ }^{260}$ Second, if an autonomous ship is designed to accommodate a pilot boarding, this could be used by pirates to board

256. UNCLOS, supra note 112 , at art 3.

257. Pilotage Act of 1987 c. $21 \S 31$ sch. 1 (Eng.).

258. Id. $\S 15$.

259. $I d$.

260. Id. 
and access the navigation system. Third, is the issue of control. If the pilot and shore-based operator (who is serving as the master) are not in the same location it poses an issue of who is in command of the ship.

To overcome the barriers of pilotage, shore-based operators could become licensed pilots for compulsory pilotage areas, alternatively autonomous vessels could be given an exemption from the pilotage requirement. However, the feasibility of these alternatives will depend on the jurisdictional requirements.

The issue of pilotage will need to be addressed internationally through remote piloting to ensure that autonomous vessels will be allowed to dock in their ports of call. In the interim ports should establishing exemptions to autonomous vessel allowing shore-based operators to remotely dock autonomous ships.

\section{CONCLUSION}

While autonomous ships are the future of the shipping industry and will provide global benefits, in order for them to become a reality current International Regulations must change to meet the evolving technology that these ghost ships represent.

The legal challenges discussed here are not insurmountable. The regulations at any level, can always be amended to accommodate new developments. The bigger question is whether there is societal acceptance and preparedness in the maritime community and beyond to make changes to accommodate unmanned shipping. If that is positive, the legal challenge is reduced to identifying the key rules that need adjustments and making the amendments. The amendments could possibly even be in the form of a generic acceptance of certain key issues of principle, such as the possibility to perform on-board functions from a remote location and the relationship between crew responsibilities and automated functions.

The most immediate challenges for ensuring the legality of unmanned shipping operations are found at the level of international technical rules, (IMO rules). This is where the most substantive tension is found in relation to the existing rules. These rules are decisive for steering the content of the jurisdictional rules of the law of the sea as well as national maritime laws worldwide. In other words, if IMO rules specifically recognized and authorized unmanned shipping operations, the regulatory challenge at the other legal levels would be significantly reduced.

Such international amendments, however, take several years to initiate and formulate and still longer to come into effect. In the interim, non-binding IMO guidelines or a best practices code for unmanned shipping operations may provide important support and assistance for flag states that see the benefits of the development and wish to support it.

Maritime liability rules seem less acute to amend but are also likely to undergo significant changes over time, as new stakeholders, new risks and possibly - new liability systems will enter the scene with unmanned shipping operations. Existing liability rules may need to be interpreted, amended and possibly supplemented by dedicated rules to supplement the traditional maritime liability framework. New liability rules, in turn, will have repercussions on 
marine insurance and other business relationships of the ship's operator.

Compulsory pilotage requirements make autonomous ships engaged in cargo carrying obsolete unless the vessel can comply with or be exempt for pilotage laws in the port state in which she intends to dock. For autonomous shipping to be viable, an international resolution will need to be reached with regards to how autonomous vessels are to be piloted.

Fortunately for autonomous ships, maritime law has proven to be flexible and willing to embrace new technology, especially if that technology makes operations safer. If the maritime industry desires autonomous vessels, legal solutions are likely to be developed and adopted to accommodate their global use. 